\title{
Program Kemitraan Telusur Lebak Pilar dalam Mendukung Pengurangan Sampah Plastik di Kota Bogor
}

\author{
Emil Radhiansyah ${ }^{1}$, Adrian Wijanarko², Faris Budiman Annas ${ }^{3}$ \\ Program Studi Hubungan Internasional, Universitas Paramadina, Indonesia
}

\begin{abstract}
ABSTRAK
Kota Bogor tengah mengusahakan pengurangan sampah plastik. Usaha ini diwujudkan dalam program Botak (Bogor Tanpa Kantong Plastik). Kebijakan larangan penggunaan kantong plastik di toko ritel modern dan pusat perbelanjaan itu diatur dalam Peraturan Wali Kota Nomor 61 Tahun 2018. Namun, kesadaran masyarakat Kota Bogor terhadap pengurangan penggunaan kantong plastik dan dampak terhadap lingkungan juga masih rendah. Oleh karena itu program pengabdian masyarakat Telusur Lebak Pilar dilaksanakan dan terdiri dari dua rangkaian acara yakni aksi bersih lingkungan di Lapangan Sempur Bogor dan dilanjutkan dengan seminar atau talkshow lingkungan bertemakan "Kemitraan dalam Integritas Pelestarian Lingkungan Untuk Mendukung SDGs 2030". Hasil pengabdian masyarakat ini menghadirkan semangat kemitraan antar sektor yakni pemerintah, institusi pendidikan dan LSM dalam menjaga lingkungan dari limbah plastik dengan memberikan informasi tentang bahaya sampah plastik dan memberikan pemahanan tentang creative thinking untuk mengubah limbah plastik sehingga memiliki nilai tambah.
\end{abstract}

Kata kunci: aksi; seminar; lingkungan; limbah; plastic; SDGs 2030

\begin{abstract}
Bogor City is working to reducing plastic waste. The City has launched program called Botak (Bogor Tanpa Kantong Plastik). The policy to ban plastic bag use in modern retail and traditional market has been regulated in Mayor Regulation Number 61 Tahun 2018. However, awareness of local people to reducing plastic bag use and the impact plastic bag to the environment still poor. Therefore, community service called Telusur Lebak Pilar was held and consisted of two agenda which is cleaning action in Sempur Bogor Field and seminar and talkshow about environment with topic "Partnership in Integrity for Environmental Conservation to Support SDGs 2030". The results of community service are to make collaboration partnership between government, educational institutions and NGOs in protecting environment from plastic waste by providing information about the dangers of plastic waste and providing understanding of creative thinking to change plastic waste so that it has added value.
\end{abstract}

Keyword: action; seminar; environment; waste; plastic; SDGs 2030 


\section{PENDAHULUAN}

Pembangunan berkelanjutan berwawasan lingkungan adalah usaha meningkatkan kualitas manusia secara bertahap dengan memerhatikan faktor lingkungan. Pembangunan berwawasan lingkungan dikenal dengan nama Pembangunan Berkelanjutan. Konsep pembangunan berkelanjutan merupakan kesepakatan hasil KTT Bumi (Earth Summit) di Rio de Janeiro, Brazil, 1992. Tidak hanya itu, kemitraan dalam mendukung pembangunan berkelanjutan yang berwawasan lingkungan pun menjadi rencana pembangunan jangka panjang PBB yang dicantumkan dalam program Sustainable Development Goals. Kemitraan Global pun menjadi salah satu goals dari 17 goals yang dicanangkan PBB dalam program SDGs.

Untuk mendukung tercapainya kesepakatan Earth Summit tersebut, pemerintah Indonesia memiliki komitmen jangka panjang untuk mengurangi sampah plastik dan pencemaran lingkungan baik di darat maupun di air. Dalam diplomasi jangka panjang Indonesia pun menggagas pertemuan Archipelagic Island State yang memiliki fokus dalam penanggulangan dan pencegahan perubahan cuaca (Climate Change). Salah satu permasalahan yang diangkat dalam forum tersebut adalah mengenai sampah plastik (plastic debris) yang saat ini tidak hanya mengotori daratan namun juga wilayah air termasuk lautan, dan sudah menyebabkan jatuhnya korban hewan. Diskusi ini menekankan bahwa pencapaian tujuan tersebut tidak hanya menjadi tanggung jawab pemerintah pusat namun juga pemerintah daerah, serta masyarakat baik individu maupun kelompok dan juga adanya peran serta lingkungan pendidikan tinggi yang semuanya merupakan agen perubahan (agent of change).

Kota Bogor merupakan salah satu kota di Provinsi Jawa Barat, Indonesia yang tengah mengusahakan pengurangan sampah plastik. Usaha ini diwujudkan dalam program Botak (Bogor Tanpa Kantong Plastik), yang merupakan kebijakan yang melarang penggunaan kantong plastik pada toko-toko ritel modern di Kota Bogor. Kebijakan larangan penggunaan kantong plastik di toko ritel modern dan pusat perbelanjaan itu diatur dalam Peraturan Wali Kota Nomor 61 Tahun 2018 tentang Pengurangan Penggunaan Kantong plastik.

Peraturan ini telah disosialisasikan berbulan-bulan sebelum kebijakan tersebut diberlakukan pada 1 Desember 2018 dan kini mulai diterapkan tahap awal di toko ritel modern dan pusat perbelanjaan (Wijanarko, 2018). Oleh karena itu, semenjak 1 Desember 2018, harapannya toko-toko ritel modern tidak lagi menggunakan kantong plastik dalam kegiatan transaksinya. Sebagai pengganti dari penggunaan kantong plastik, pemerintah Kota Bogor memperkenalkan Kantong Belanja Guna Ulang. Kantong tersebut terbuat dari serat singkong. Ada juga tas belanja dari bahan daur ulang. Kantong ramah lingkungan itu bisa didapatkan warga di pasar swalayan tempat berbelanja dengan harga bervariasi antara Rp 10.000 sampai Rp 12.000. 


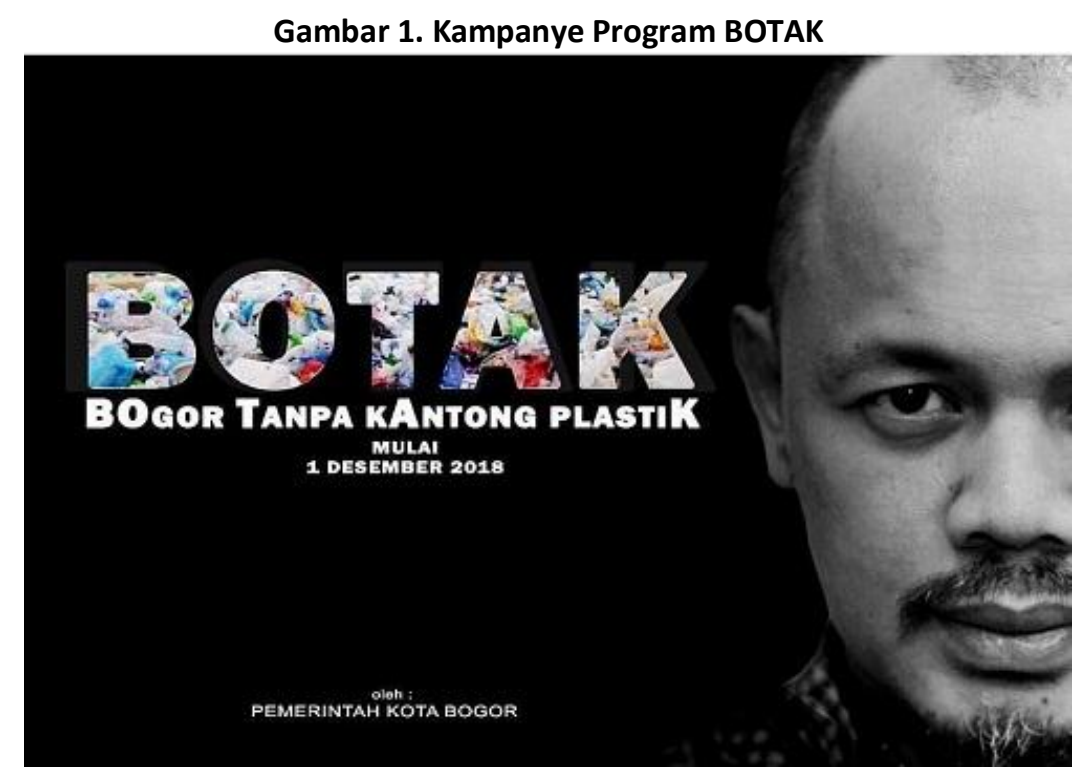

Sumber: Bogor-Kita.com

Upaya pemerintah Kota Bogor dalam pengurangan penggunaan kantong plastik melalui program BOTAK merupakan salah satu bentuk usaha yang dilakukan oleh pemerintah daerah dalam mendukung tercapainya kesepakatan Earth Summit, dan mendukung komitmen jangka panjang pemerintah Indonesia untuk mengurangi sampah plastik dan pencemaran lingkungan baik di darat maupun di air.

Kota Bogor adalah kota keempat yang memberlakukan pelarangan penggunaan kantong plastik setelah Banjarmasin, Balikpapan, dan Bandung. Namun, dalam pelaksanaan program BOTAK (Bogor Tanpa Kantong Plastik) ini tentu tidak semudah membalikkan tangan. Menurut Walikota Bogor, Bima Arya, sebagian besar toko ritel sudah menerapkan kebijakan tersebut walau tidak menutup kemungkinan ada beberapa toko ritel yang masih menggunakan kantong plastik dengan alasan menghabiskan stok yang ada. Menurutnya, tahap awal masih diperbolehkan selama masa sosialisasi, tetapi ke depan, akan diberlakukan sanksi bagi yang melanggar kebijakan pemerintah seperti pencabutan izin, denda, dan kurungan (Bogor Kita, 2018). Pedagang-pedagang di pasar tradisional pun masih perlu menyesuaikan diri secara bertahap terhadap kebijakan ini.

Pelaksanaan program BOTAK secara bertahap ini tentu dapat mengurangi penggunaan sampah plastik. Kepala Dinas Lingkungan Hidup Kota Bogor, Ellia Buntang menjelaskan bahwa kebijakan larangan penggunaan kantong plastik diyakini bisa mengurangi sampah plastk secara signifikan³. "Dari 23 gerai yang ada di Kota Bogor, dihasilkan 1,8 ton per hari kantong plastik dan dengan kebijakan ini kita kurangi secara signifikan," katanya. Ellia Buntang juga menjelaskan bahwa sampai Maret 2019 masih ada toko yang menggunakan plastik berlabel ecoplastik dan SNI. Setelah masa itu, seluruh toko wajib mengikuti aturan tidak menyediakan kantong plastik (Permana, 2019). 
Tantangan lainnya adalah kesadaran masyarakat Kota Bogor terhadap pengurangan penggunaan kantong plastik dan dampak buruknya juga masih menjadi perhatian. Kesadaran warga masyarakat terhadap dampak buruk dari penggunaan sampah plastik sebenarnya bukan hanya menjadi polemik bagi warga Kota Bogor, namun juga bagi masyarakat Indonesia secara umum. Sebagai contoh, pada sudut kota di lapangan sempur, Kota Bogor, masih banyak terlihat sampah plastik padahal pada lokasi ini telah disediakan banyak tempat sampah (Radbogmin, 2017).

Dalam kamus Merriam-Webster terdapat dua pengertian mengenai lingkungan (environment) yaitu the circumstances, objects, or conditions by which one is surrounded (suatu lingkungan, objek, atau kondisi yang mengelilingi seseorang), sementara yang pengertian yang kedua adalah the complex of physical, chemical, and biotic factors (such as climate, soil, and living things) that act upon an organism or an ecological community and ultimately determine its form and survival (suatu faktor phisik yang kompleks, komponen kimia dan biotik (seperti iklim, tanah, dan makhluk hidup) yang bertindak sebagai sebuah organisme atau komunitas ekologi dan menentukan bentuk kehidupan dan kelangsungan hidupnya). Dari pengertian ini dapat ditarik suatu pengertian bahwa lingkungan merupakan kondisi alam yang menaungi organisme hidup dimana ia (organisme hidup) menentukan bentuk dan kelangsungan hidupnya.

Dalam lingkungan terdapat dua pandangan mengenai kepentingan manusia yaitu pandangan yang bersifat antropocentrism, yaitu pandangan yang melihat bahwa pentingnya melindungi dan menjaga keberlanjutan alam demi kepentingan manusia dimasa mendatang. Pandangan tersebut merasa bahwa manusia sebagai pengguna alam merasa berkewajiban untuk menjaga alam untuk menjamin keberlanjutan manusia di masa mendatang, dalam hal ini manusia bukan menjadi bagian alami dari lingkungan itu sendiri dan bertindak sebagai pencipta lingkungan. Pandangan berikutnya bersifat ecocentrism, yaitu pandangan yang melihat pentingnya melindungi alam untuk kepentingan alam itu sendiri. Dari sisi ini manusia dianggap sebagai bagian alami dari lingkungan dan segala tindakan manusia untuk menjaga alam adalah demi lingkungan itu sendiri (Ari \& Gökpınar, 2019).

Walaupun kedua pandangan tersebut terlihat berseberangan terutama mengenai bagaimana campur tangan struktur (pemerintahan) terhadap keberlangsungan lingkungan hidup itu sendiri, namun keduanya memiliki konsern terhadap perlunya perlindungan terhadap alam melalui komitmen politik pemerintah sebagai pembuat dan implementasi kebijakan.

Kemitraan pada dasarnya merupakan gotong-royong atau kerjasama dari berbagai pihak, baik secara individual maupun kelompok. kemitraan adalah suatu kerja sama formal antara individu-individu, kelompok-kelompok atau organisasi- organisasi untuk mencapai suatu tugas atau tujuan tertentu (Natoadmodjo, 2013 dalam Uji, 2016). Pendapat lainnya menjelaskan bahwa kemitraan, kemitraan merupakan sebuah bentuk sinergi kerjasama antar 
dua atau lebih individu/organisasi yang terbangun akibat adanya komitmen dan komunikasi untuk mencapai tujuan bersama yang diinginkan (Wahyudi dan Manaf, 2013).

Mohr dan Spekman (1994) dalam Wahyudi dan Manaf (2013) menjelaskan bahwa terdapat beberapa unsur atau atribut kemitraan diantaranya adalah komitmen, koordinasi, saling ketergantungan, dan kepercayaan. Elemen komitmen, merupakan kesediaan mitra untuk mengerahkan usaha atas nama hubungan. Ini menunjukan sebuah orientasi masa depan dimana setiap mitra berusaha untuk membangun hubungan yang bisa mengatasi permasalahan yang tidak terduga. Komitmen yang tinggi ditunjukan bilamana kedua belah pihak dapat mencapai tujuan individu bersama tanpa memperlihatkan prilaku untuk mencari keuntungan.

Elemen koordinasi menjelaskan bahwa kemitraan yang berhasil ditandai dengan tindakan tindakan yang terkoordinasi dan diarahkan pada tujuan bersama yang konsisten. Elemen saling ketergantungan, terbentuknya sebuah kemitraan didasari oleh saling ketergantungan satu dengan yang lainnya. Kedua belah pihak mengakui bahwa keuntungan dari saling ketergantungan memberikan manfaat lebih besar dari baik daripada dilakukan sendiri. Sedangkan elemen kepercayaan juga merupakan elemen yang penting dikarenakan bahwa kurangnya kepercayaan akan merusak untuk bertukar informasi, kelancaran hubungan timbal balik, dan akan mengurangi efektivitas pemecahan masalah bersama.

Tennyson (2011) menjelaskan bahwa kemitraan yang dilakukan oleh suatu organisasi dengan organisasi pada sektor lainnya dapat memberikan beberapa nilai positif berikut di antaranya, 1) Kemitraan mampu menciptakan setiap sektor agar dapat berbagi kompetensi dan kapasitasnya masing-masing dalam rangka mencapai tujuan bersama secara lebih efektif dan berkelanjutan. 2) Kemitraan mampu memberikan akses yang lebih terhadap sumber daya baik sumberdaya teknis, manusia, pengetahuan, maupun finansial dari semua sektor. 3) Jejaring baru yang lebih dinamis menawarkan setiap sektor agar lebih terhubung dengan masyarakat yang lebih luas sehingga memiliki kapasitas yang lebih besar untuk mempengaruhi agenda kebijakan. 4) Melalui kemitraan maka setiap sektor akan lebih terintegrasi dalam memahami nilai-nilai yang disepakati bersama.

\section{METODE PELAKSANAAN}

Untuk membantu pemerintah kota Bogor menyelesaikan permasalahan yang diuraikan pada penjelasan sebelumnya. Universitas Paramadina bersama dengan Pemerintah Kota Bogor merumuskan suatu solusi berupa kegiatan Telusur Lebak Pilar. Kegiatan ini juga merupakan hasil diskusi dan kerjasama dengan berbagai pihak diantaranya Komunitas Bogor Clean Action, SMA Negeri 5 Bogor serta didukung oleh Ford Foundation. Telusur Lebak Pilar merupakan kegiatan yang terdiri dari dua rangkaian acara yakni aksi bersih lingkungan di 
Lapangan Sempur Bogor dan dilanjutkan dengan seminar atau talkshow lingkungan bertemakan "Kemitraan dalam Integritas Pelestarian Lingkungan Untuk Mendukung SDGs 2030".

Sebelum dilakukan pelaksanaan program, perwakilan Tim Universitas Paramadina telah melakukan survey (pengamatan dan penelusuran) terhadap lokasi bersama dengan tim dari Komunitas Bogor Clean Action pada 16 Desember 2018. Kegiatan pertama adalah aksi bersih lingkungan yang dilaksanakan di sekitaran Lapangan Sempur Kota Bogor. Dalam Bakti Lingkungan Telusur lebak Pilar dilaksanakan oleh 90 peserta yang terdiri dari mahasiswa Universitas Paramadina, Pelajar SMA Negeri 5 Kota Bogor dan Komunitas Bogor Clean Action (Lensa Online, 2018). Kegiatan ini dibuka oleh Walikota Kota Bogor, Bima Arya. Ph.D., dan Rektor Universitas Paramadina, Firmanzah, Ph.D., serta didampingi oleh Lurah Sempur, Rena Da Frina. Aksi ini dilaksanakan dari pukul 09.00-11.30 WIB, meliputi bentuk kegiatan pemungutan sampah yang dimulai dari Lapangan Sempur Kota Bogor dan bertahap terhadap sepanjang bantaran Sungai Ciliwung yang melintasi Kampung Lebak Pilar, Kelurahan Sempur, Kecamatan Bogor Tengah. Peserta aksi dibagi menjadi beberapa kelompok dan melakukan pemungutan sampah terutama sampah plastik yang ada di sekitaran lapangan Sempur dan Sepanjang bantara kali ciliwung di desa lebak pilar.

Kegiatan kedua yang dilakukan adalah talkshow dilaksanakan di Ruang Paseban Sri Bima, Balai Kota Bogor, serta diikuti oleh pelajar dari SMAN 5 Kota Bogor, Komunitas dan Mahasiswa Universitas Paramadina. Dalam kegiatan tersebut dihadirkan empat narsumber yaitu Bima Arya Sugiarto Ph.D (Walikota Kota Bogor), Hendriana Werdhaningsih (Dosen Universitas Paramadina), Agil Mulqi (Koordinator Komunitas Bogor Clean Action/ BCA) dan Rahyang R.P. Nusantara (Gerakan Indonesia Diet Kantong Plastik/ GIDKP).

Talkshow ini berisikan prespektif dari berbagai institusi terhadap masalah lingkungan. Walikota Kota Bogor menjelaskan dari presprektif pemerintah tentang fakta dan data sampah plastik di Kota Bogor dan kegiatan yang telah dilakukan oleh pemerintah. Sedangkan Koordinator Komunitas Bogor Clean Action menjabarkan kegiatan yang telah dilakukan untuk menjaga lingkungan. Dosen Universitas Paramadina menberikan penjelasan tentang materi creative thinking. Dalam penjelasan tersebut digaris-bawahi tentang perlunya kreatifitas untuk mengelola sampah plastik dan sebagainya menjadi bahan yang dapat didaur ulang. Contoh barang yang didaur ulang juga dijelaskan seperti barang kerajinan sampai dengan perlengkapan rumah tangga. Sedangkan Gerakan Indonesia Diet Kantong Plastik menjelaskan bahwa persprektif bahwa dengan melakukan kegiatan seperti mengurangi sampah kantongn plastik sangat dapat membantu untuk menjaga kebersihan lingkungan dan menjaga ekosistem setempat. 


\section{HASIL DAN PEMBAHASAN}

Menurut Wahyudi dan Manaf (2013), kemitraan merupakan sebuah bentuk sinergi kerjasama antar dua atau lebih individu/organisasi yang terbangun akibat adanya komitmen dan komunikasi untuk mencapai tujuan bersama yang diinginkan. Kegiatan Telusur Lebak Pilar merupakan hasil kerja sama antara lebih dari tiga organisasi di antaranya Universitas Paramadina, Pemerintah Kota Bogor, Komunitas Bogor Clean Action dan SMA Negeri 5 Bogor.

Tennyson (2011) menjelaskan bahwa kemitraan yang dilakukan oleh suatu organisasi dengan organisasi pada sektor lainnya dapat memberikan beberapa manfaat atau nilai positif berikut di antaranya: (1) Kemitraan mampu menciptakan setiap sektor agar dapat berbagi kompetensi dan kapasitasnya masing-masing dalam rangka mencapai tujuan bersama secara lebih efektif dan berkelanjutan. Dengan bermitra bersama komunita Bogor Clean Action, maka setiap pemangku kepentingan dalam program Telusur Lebak Pilar dapat berbagi peran sesuai dengan kompetensi dan kapasitasnya. Misalnya dalam kegiatan ini, Universitas Paramadina dan Ford Foundation berperan sebagai penyadang dana, sedangkan komunitas Bogor Clean Action berperan dalam menemukan akar permasalahan kebersihan yang perlu dipecahkan dalam kegiatan ini. (2) Kemitraan mampu memberikan akses yang lebih terhadap sumberdaya baik sumberdaya teknis, manusia, pengetahuan, maupun finansial dari semua sektor. Pada kegitan Telusur Lebak Pilar, komunitas Bogor Clean Action menyumbangkan sumberdaya teknis dan pengetahuan yang mereka miliki. Komunitas Bogor Clean Action menjadi pemandu ahli dalam kegiatan pemungutan sampah di sungai Ciliwung, selain itu komunitas ini memberikan dalam mengarahkan sukarelawan lainnya mengenai cara pemungutan sampah atau operasi semut yang baik dan benar. (3) Jejaring baru yang lebih dinamis menawarkan setiap sektor agar lebih terhubung dengan masyarakat yang lebih luas sehingga memiliki kapasitas yang lebih besar untuk mempengaruhi agenda kebijakan. Kemitraan Program Telusur Lebak Pilar yang menggandeng pemerintah Kota Bogor, membuat kegiatan ini menjadi lebih terekspose ke masyarakat umum, hal ini dikarenakan kegiatan ini menjadi agenda pemerintah dan diliput oleh berbagai media massa lokal dan nasional. (4) Melalui kemitraan maka setiap sektor akan lebih terintegrasi dalam memahami nilai-nilai yang disepakati bersama. Kegiatan Telusur Lebak Pilar dapat terlaksana dikarenakan setiap aktor atau pemangku kepentingan yang terlibat memiliki visi dan nilai yang sama. Baik Universitas Paramadina, Komunitas Bogor Clean Action, Pemerintah Kota Bogor dan SMA Negeri 5 Bogor sama-sama memiliki kepedulian perihal permasalahan lingkungan khususnya pengendalian sampah plastik di Kota Bogor. Atas dasar inilah, beberapa institusi tersebut saling bekerja sama untuk melaksanakan program Telusur Lebak Pilar demi perwujudan visi yang sama.

Kegiatan Telusur Lebak Pilar melihat bahwa kolaborasi berbagai pihak baik pemerintah, LSM, komunitas dan institusi akademik merupakan komponen yang penting dalam mewujudkan masyarakat yang berintegritas dalam upaya pelestarian dan kebersihan lingkungan. Dalam 
proses pelaksanaan kegiatan ini, Universitas Paramadina menggandeng beberapa mitra selain pemerintah yakni masyarakat Kota Bogor yang terdiri dari Komunitas yang bergerak di bidang lingkungan khususnya terkait sampah plastik (Bogor Clean Action) dan Pelajar Sekolah Menengah Atas di Kota Bogor.

\section{Pemerintah Kota Bogor}

Pemerintah merupakan stake holder yang penting, hal ini dikarenakan perlu adanya political will dari pemimpin pemerintahan bersama sama dengan aparatur pemerintahan lainnya dan seluruh elemen masyarakat (Lemabaga Edukasi, LSM, dan Individual) mencapai kepentingan bersama. Pemerintah Kota Bogor merupakan pengemban amanah dari masyarakat Kota Bogor melalui pembuatan kebijakan dan penerapannya.

Salah satu target pemerintah Kota Bogor adalah mengurangi penggunaan kantong plastik yang berpotensi mencemari wilayah Kota Bogor, terutama menjadi limbah di sungai. Kota Bogor merupakan salah satu penyumbang sampah sebesar 700 ton dengan 1,7 ton merupakan sampah plastik. Program yang diusung oleh Pemerintah kota Bogor adalah Bogor Tanpa Kantok Plastik (BOTAK) telah diterapkan sejak awal Desember 2018 lalu dan merupakan penerapan dari kebijakan dan komitmen yang memang juga telah dicanangkan oleh pemerintah pusat.

Program yang dilaksanakan oleh Pemerintah Kota Bogor selaras dengan program yang diusung oleh Universitas Paramadina, dan diharapkan dapat ditiru oleh pemerintah kota lainnya di Indonesia. Selain itu bersama dengan Pemerintah Kota Bogor meyakinkan masyarakat kota bogor bahwa kebersihan dan kenyamana lingkungan hanya dapat diwujudkan melalui perubahan perilaku.

\section{Institusi Pendidikan}

Institusi pendidikan memiliki fungsi mengembangkan pengetahuan dan memberikan suatu solusi melalui telaah akademis terhadap permasalahan yang terjadi pada ranah sosial. Oleh karenanya, Institusi pendidikan merupakan lembaga yang memiliki peran penting dalam memberikan edukasi, pembelajaran dan memberikan pengaruh dalam terjadinya perubahan sosial masyarakat. Dalam program pengabdian masyarakat ini melibatkan dua insitusi pendidikan yaitu Universitas Paramadina mewakili institusi perguruan tinggi dan SMA Negeri 5 Kota Bogor merupakan lembaga pendidikan di bawah naungan pendidikan dasar dan menengah.

Dilibatkannya dua institusi pendidikan ini adalah untuk menciptakan kesadaran terhadap masyarakat secara luas mengenai persoalan plastik sampah yang tidak dapat terurai secara alami dan memiliki potensi mencemarkan lingkungan, dan secara khusus terhadap masyarakat yang tinggal di bantaran daerah aliran sungai Ciliwung, Desa Lebak Pilar, Bogor mengenai penumpukan sampah di daerah aliran sungai tersebut. 
Universitas Paramadina memandang bahwa perlu adanya suatu gerakan penyadaran terhadap bahaya penggunaan plastik dan sampah yang ditimbulkan. Melalui program ini diberikan informasi bahwa adanya alternatif lain pengganti plastik yang dapat digunakan oleh masyarakat sehari hari. Dalam program ini dilibatkan mahasiswa yang tidak hanya bertindak sebagai aktor pelaku yang terlibat dalam kegiatan namun sekaligus berperan dalam menelaah keadaan yang riil dari situasi yang dihadapi oleh masyarakat dan lingkungan di Lebak Pilar.

Keterlibatan pelajar dari SMA Negeri 5 Kota Bogor merupakan bagian dari pembelajaran penyadaran mengenai lingkungan hidup, diharapkan para pelajar yang terlibat dapat berkontribusi lebih terhadap lingkungan utamanya dari tempat tinggal dan sekolah. Pada acara aksi bersih lingkungan para generasi muda dilihatkan kepada pentingnya dalam menjaga lingkingan hidup. Terlihat banyak sampah yang bertebaran di lingkungan sekitar masyarakat.

Pada acara talkshow, para siswa SMA Negeri 5 Kota Bogor diajarkan bagaimana cara yang mudah dalam merawat lingkungan. Siswa diberi pemahamam tentang sampah plastik yang sudah menjadi ancaman apabila tidak ditangani dengan serius. Pemateri menjabarkan bentuk-bentuk kreatif dengan tema creative thinking untuk mengelola bahan baku sampah plastik. Produk seperti kesenian, kerajinan tangan sampai dengan perlatan rumah tangga dapat dibuat kembali dari limbah plastik yang dimanfaatkan oleh masyarakat. Luaran dari talkshow adalah untuk memberikan informasi kepada para siswa untuk dapat berpikir kreatif dengan memberikan nilai tambah, manfaat ekonomis dan jiwa entrepreneurship. Tentunya juga yang utama para generasi muda diajak dari dini untuk dapat mengurangi penggunaan kantong plastik.

\section{Komunitas / Lembaga Swadaya Masyarakat}

Dalam program yang diusung turut serta melibatkan salah satu komunitas yang peduli dan bergerak dalam hal persoalan sampah. Bogor Clean Action merupakan komunitas yang berdiri secara mandiri sejak tahun 2014 dan telah terlibat dalam kampanye penyadaran sampah terhadap masyarakat Bogor. Setiap akhir pekan komunitas ini melaksanakan aksi pemungutan sampah di Lapangan Sempur Bogor setelah kegiatan car free day.

Dalam studi ilmu sosial, komunitas yang didirikan oleh masyarakat merupakan bentuk dari suatu Lembaga Swadaya Masyarakat (LSM) atas permasalahan-permasalahan yang timbul secara spesifik di masyarakat. Komunitas dan LSM yang ada memiliki peran aktif dan bergerak secara langsung di dalam masyarakat, dan sekaligus berperan sebagai kelompok kepentingan (interest group) dalam memberikan input terhadap pemerintahan mengenai isu yang diusung dan solusi yang diharapkan dari pemerintah dengan munculnya suatu kebijakan dan penerapannya. Kemitraan dengan Bogor Clean Action dalam program ini adalah berusaha menunjukkan kepada masyarakat bahwa kepedulian terhadap lingkungan dimulai dari diri sendiri dan secara bersama sama melakukan gerakan nyata untuk menyelamatkan 
lingkungan, dan diharapkan akan tumbuh komunitas-komunitas lainnya sebagai efek berantai dalam isu lingkungan di Kota Bogor.

\section{SIMPULAN}

Masalah lingkungan dalam kota besar seperti Bogor bukan menjadi tanggung jawab pemerintah saja. Partisipas masyarakat perlu dihidupkan dalam menjaga kebersihan dan kesehatan lingkungan. Melalui pengabdian masyarakat ini, Universittas Paramadina dengan dukungan Ford Foundation memberikan hasil yang konkrit bagi masyarakat yaitu: (1) Masalah lingkungan merupakan masalah bersama. Oleh karena itu dalam pengabdian masyarakat ini, Universitas Paramadina mencoba menghidupkan semangat kemitraan untuk mencapai tujuan bersama. Pemerintah Kota Bogor, komunitas Bogor Clean Action dan SMA Negeri 5 Kota Bogor, yang merupakan stakeholder Kota Bogor, diundang bersama untuk melakukan aksi yang konkrit untuk menjaga lingkungan sekitar. (2) Pertisipasi masyarakat perlu dihidupkan untuk menumbuhkan semangat dalam menjaga lingkungan untuk dapat mengurangi limbah plastik. Untuk itu talkshow dilakukan dalam kegiatan ini. Dalam kegiatan ini diberkikan pemahaman dari berbagai prespektif baik dari pemerintah, institusi pendidikan dan LSM. Luaran dari kegiatan ini dapat memberikan pemahaman kepada generasi muda, khususnya SMA Negeri 5 Kota Bogor, tentang bahaya limbah plastik. (3) Salah satu materi dalam talkshow yang disampaikan adalah creative thinking. Pada materi ini diajarkan perlunya pemikiran kreative untuk mengelola limbah plastik. Pengelolaan limbah plastik menjadi kerajinan rumah tangga sampai dengan kerajinan tangan diharapkan dapat memberikan nilai edukasi entrepreneurship dan kreativitas kepada seluruh peserta, khususnya generasi muda.

\section{UCAPAN TERIMA KASIH}

Tim peneliti mengucapkan terima kasih kepada Ford Foundation yang mendukung kegiatan pengabdian masyarakat ini. Selain itu tim juga mengapresiasi kepada semua pihak baik dari tim Universitas Paramadina, Pemerintah Kota Bogor, komunitas Bogor Clean Action serta SMA Negeri 5 Bogor yang ikut berpartisipasi dan menyukseskan kegiatan Telusur Lebak Pilar. 


\section{DAFTAR PUSTAKA}

Ari, Tayyar \& Gökpınar, Fatih. (2019). Green Theory in International Relations. Anadolu University Publication. Diakses melalui https://www.researchgate.net/publication/ 332183190_Green_Theory_in_International_Relations

Bogor Kita. (Minggu, 2 Desember 2018). Tak Dukung Program Botak Izin Toko Bisa Dicabut. Diakses melalui https://bogor-kita.com/tak-dukung-program-botak-izin-toko-bisadicabut/

Lensa Online. (Sabtu, 19 Desember 2018). Gelar Aksi Telusur Lebak Pilar Dukung Program Botak. Diakses melalui https://www.lensaonline.com/gelar-aksi-telusur-lebak-pilardukung-program-botak/

Permana, Muhammad Sidik. (Jumat, 4 Januari 2019). Dinas LH Bogor: Larangan Plastik Kurangi 1,8 Ton Sampah Sehari. Diakses melalui https://metro.tempo.co/read/1161470/ dinasIh-bogor-larangan-plastik-kurangi-18-ton-sampah-sehari

Radar Bogor. (Senin, 3 Juli 2017). Taman Sempur Bukan Tempat Sampah. Diakses melalui http://www.radarbogor.id/2017/07/03/taman-sempur-bukan-tempat-sampah/

Tennyson, R. (2011). The Partnering Toolbook. The Partnering Initiative: International Business Leader Forum.

Uji, A. Y. T. (2016). Kemitraan pemerintah dan swasta dalam pembangunan bandara swadaya sangia nibandera kabupaten kolaka. JAKPP (Jurnal Analisis Kebijakan \& Pelayanan Publik), 1(2), 169-182.

Wahyudi, I., \& Manaf, A. (2013). Kemitraan pemerintah daerah dengan masyarakat dalam kegiatan penataan lingkungan permukiman berbasis masyarakat di jawa tengah. Teknik PWK (Perencanaan Wilayah Kota), 2(3), 678-686.

Wijanarko, Y. (2018, 2 Desember). Botak, kota bogor tanpa kantong plastik. Diperoleh dari https://www.pikiran-rakyat.com/jawa-barat/2018/12/02/botak-kota-bogor-tanpakantong-plastik-433931 